\title{
Covid-19 Pandemisinde Yoğun Bakım Triyajı Bağlamında Hazırlanan Klinik Etik Rehberlerin Normatif Analizi ve Etik Değerlendirmesi
}

\section{Normative Analysis and Ethical Evaluation of Clinical Ethical Guidelines Published in the Context of Intensive Care Triage During Covid-19 Pandemic}

\author{
Esra Aksoy ${ }^{1}$, Merve Nur Koçak Öztürk ${ }^{1}$, İlhan İlkılıç ${ }^{\circledR}$
}

\footnotetext{
1 İstanbul Üniversitesi, Sağlık Bilimleri Enstitüsü, Tip Tarihi ve Etik Anabilim Dalı, İstanbul, Türkiye
}

ORCID: E.A. 0000-0003-4332-0576;

M.N.K. 0000-0002-8496-7563;

İ.İ. $0000-0002-4250-8676$

Sorumlu Yazar/Corresponding Author: İlhan İlkılıç,

İstanbul Üniversitesi, Sağlık Bilimleri Enstitüsü, Tip Tarihi ve Etik Anabilim Dalı, İstanbul, Türkiye E-posta: ilhan.ilkilic@istanbul.edu.tr

Geliş tarihi/Submitted: 31.05 .2021 Kabul Tarihi/Accepted: 29.07.2021 Online Yayın/Published Online: 20.10.2021

Atıf/Citation: Aksoy E, Kocak Ozturk MN, Ilkilic I. Normative analysis and ethical evaluation of clinical ethical guidelines published in the context of intensive care triage during Covid-19 pandemic. Sağlık Bilimlerinde İleri Araştırmalar Dergisi 2021; 4(Suppl.1): S19-S36.

https://doi.org/10.26650/JARHS2021-945971
ÖZ

Covid-19 Pandemisi sürecinde vaka sayılarının belli dönemlerde hızla yükselmesi yoğun bakım ünitelerinde yüksek doluluk oranlarına sebep olmuștur. Hasta sayısında yașanan bu ani ve hızlı yükseliş karşısında tıbbi kaynakların yetersiz kalması ihtimali ve tecrübeleri yoğun bakım hizmetlerinde kaynakların acil ve adil dağıtımı ile ilgili etik tartışmaları başlatmışırır. Bu durum sadece etik tartışmalara ivme kazandırmakla kalmamış aynı zamanda Avrupa'daki birçok tıbbi meslek kuruluşu yoğun bakım triyajı için etik kriterler içeren rehberler yayınlamıştır. Bu çalışmada Avrupa’da yayınlanan bazı klinik-etik triyaj rehberleri normatif analize tabi tutularak etik açıdan değerlendirilmiştir.

Amaç: Almanya, Avusturya, Belçika, Fransa, İngiltere, İsviçre ve İtalyảnın yoğun bakım derneklerinin triyaj için yayınlamış olduğu rehberlerin içerdikleri genel parametreleri ve normatif kavramları belirlemek ve bunların eleştirel bir değerlendirmesinden ortaya çıkan sonuçları tespit etmektir.

Gereç ve Yöntem: Yukarıda adı geçen ülkelerin yoğun bakım ve anestezi derneklerinin Covid-19 pandemisi bağlamında yayınladıkları triyaj rehberlerinin eleștirel normatif analizi ve etik prensiplere göre değerlendirilmesi.

Bulgular: İncelenen triyaj rehberleri ortak parametreler ve benzer normatif kavramlar kullanmış olmasına rağmen, birbirleri arasında önemli farklar bulunmaktadır. Bu farklılıkların kullanılan triyaj kriterleri, triyaj hedefleri, yaş faktörü, bazı sosyal gruplara öncelik verilmesi, ilk müdahale yapılması ve Covid-19 hastalarına farklı uygulama yapılması alanlarında olduğu tespit edilmiștir.

Sonuç: Triyaj rehberlerini yayınlayan Avrupa ülkeleri aynı kültür geleneğinden gelse bile triyaj rehberlerinde kullandıkları kriterlere ve normatif kavramlara farklı değerler atfedilmiş ve farklı öncelikler verilmiştir. Bu farklılıkların oluşmasında güncel siyasi yaklaşımlar ve geçerli etik kültür etkili olabildiği gibi, o ülkenin hali hazırdaki maddi ve sosyo-kültürel kaynakları ve bu kaynakların kullanılmasındaki stratejileri de önemlidir. Bu bağlamda ülkemizde etik triyaj rehberlerine ihtiyaç duyulduğunda acilen hazırlanmalı ve hazırlanma sürecinde tüm bu noktalar göz önüne alınmalıdır.

Anahtar Kelimeler: Covid-19, triyaj, kısıtl kaynakların adil dağıtımı, etik rehberler, yoğun bakım

\section{ABSTRACT}

Throughout the COVID-19 pandemic, the rapid increase in the number of cases during certain periods has caused a high occupancy rate in intensive care units. Faced with a sudden and rapid increase in the number of patients, a lack of medical resources or its possibility led to ethical discussions on the immediate and equitable distribution of resources in intensive care units. This has not only given impetus to the ethical debate, but many medical professional organisations in Europe have published guidelines for triage of critical care which contain ethical criteria. In this study, some of the ethical triage guides have been normatively analyzed and ethically evaluated.

Objective: The aim of this study is to identify and determine the parameters and normative concepts contained in the guidelines for triage published by the intensive care associations of Germany, Austria, Belgium, France, England, Switzerland and Italy. The results of this investigation were also critically and ethically evaluated and reflected.

Materials and Methods: Critical normative analysis and ethical evaluation of clinical ethical guidelines published by intensive care and anaesthesia associations of the above-mentioned countries. 
Results: Although the studied triage guides used common parameters and similar normative concepts, there are significant differences between them. These differences were determined to be related to the triage criteria used, triage objectives, age factor, priority given to certain social groups and the application of different treatments to Covid-19 patients.

Conclusion: Although the European countries that have published triage guides come from the same cultural tradition, the normative criteria and concepts they used in the triage guides are considered different values and priorities in their rankings. These differences may be due to the current political and ethical culture, also to the current economic and socio-cultural resources and their strategies for using their resources. Because of these facts and the reasons which we found, they should be considered in the preparation of ethical triage guidelines in Turkey.

Keywords: Covid-19, triage, resource allocation, ethical guidelines, intensive care 


\section{GİRIŞ}

Covid-19 Pandemisi 2019 yılının sonunda ortaya çıkıp modern ulaşım imkânlarıyla tüm dünyaya hızla yayılmış ve Dünya Sağlık Örgütü’nün verilerine göre günümüzde dünyanın beş kıtasında ve yaklaşı 200 ülkesinde tespit edilmiştir (1). Bu hızlı yayılma başta sağlık alanında olmak üzere ekonomi, eğitim, sanayi turizm gibi birçok alanda, psikolojik, sosyal, hukuki ve etik açıdan birbirinden farklı, çok sayıda sorunlara yol açmıştır. Diğer taraftan en fazla sorunun yaşandığı sağlık alanında ise beklenen hizmet ihtiyacının hızla artması ve kaynakların sınırlı olmasından dolayı acil çözüm bekleyen meseleler doğurmuştur. Bu hastalığın tıp tarihinde yeni olması, hakkında bilimsel bilgi ve tecrübenin olmaması ve mevcut etkili ilaçların bulunmaması ise bu mücadelede başarılı olmayı güçleştirmiştir. Bu çeşitli sorunlar arasında yoğun bakım hizmetlerindeki sınırlı kaynaklar, sonuç itibarıyla insan hayatının kaybedilmesi ile direkt ilişkili olduğu için ayrı bir öneme sahiptir (2).

Covid-19 enfeksiyonun 2020 yılının başında bazı Avrupa ülkelerinde tespit edilmesi ve hızla yayılması bu ülkelerin bazılarının yoğun bakım hizmetlerinde önemli aksamalara yol açmış ve ölüm oranlarını arttırmıştır. Örneğin İtalya'da 30 Ocak 2020'de ilk vaka tespit edilmesine rağmen 21 Mart'ta günlük 6.557 yeni enfeksiyona ve 27 Martta ise bir günde 969 ölüme yol açarak en yüksek seviyelerine ulaşmıştır (3). Yine bu ülkede Covid-19 testi pozitif çıan hastaların 2020 yılı mart ayının başında \%11,2 sinin yoğun bakım tedavilerine ihtiyacı olurken, 100.000 kişiye düşen yoğun bakım yatağının 8,42 olması ciddi bir eksiklik oluşturmuştur.(3) Almanya'da 100.000 kişiye 33,9 Avusturya’da ise 28,9 olduğu göz önüne bulundurulursa İtalya’nın yoğun bakıma ayırdığı kaynakların azlığı ortaya çıkmaktadır (3). Bu durum sadece İtalya'da değil benzeri durumda olan İspanya ve Belçika'da da triyaj yapma zorunluluğunu beraberinde getirmiştir.

Böylesi durumlar Avrupa ülkelerinde yoğun bakım ünitelerindeki kaynak yetersizliğinden dolayı hastaların tedavilerinde önceliklendirmeye gidilmesi, triyaj konusundaki etik tartışmalara ivme kazandırmış ve Avrupa'daki birçok tıbbi meslek kuruluşu kısa zamanda bu alanda etik kriterler içeren triyaj rehberleri yayınlamıştır. Ülkemizde de Covid-19 Pandemisinin yoğun seyrettiği dönemlerde İtalyałaki gibi olmasa bile benzer sorunlar yaşanmış fakat herhangi bir etik triyaj rehberi çalışması maalesef yapılmamıștır. Böylesi rehberlere bilimsel bir temelin oluşturulması amacıyla, bu çalışmada Avrupa'da yayınlanan bazı etik triyaj rehberleri incelenmiş, burada kullanılan farklı parametreler ve normatif kriterler karşılaştırılmış ve eleştirel bir analize tabi tutulmuştur.

\section{Triyaj Kavramı}

Triyaj kavramı, Fransızca bir kelime olan "trier" kelimesinden gelmekte olup seçmek, ayıklamak ve ayırmak anlamına gelmektedir (4). Sağlık hizmetinde ise tedaviye alınacak olan yaralıların veya hastaların önceliklerini belirleyen prosedürü ifade etmektedir (5). Covid-19 Pandemisi ile tekrar gündeme gelen triyaj uygulaması aslında savaştaki askerleri kategorize etmek için ortaya çıkmış ve yirminci yüzyılın ikinci yarısında ise sivil alanlarda da kullanılmaya başlanmış ve takriben 200 yıllık geçmişi olan bir yöntemdir. En genel ifadeyle, yoğun bakımlarda uygulanan triyajın kaynakların sinırlı olmasından dolayı herkesi kurtarmayı hedefleyen idealist bir yaklaşım değil, çok sayıda yaşamı kurtarmayı, ya da en az kayıp vermeyi hedefleyen realist bir yöntem olduğu söylenebilir (6). İçinde bulunduğumuz pandemi şartları ile savaş ve doğal afet şartlarının aynı olmaması, Covid-19 Pandemisindeki uygulanan triyajı da farklı hale getirmiştir. Örneğin yerel ve ülke sathındaki farklı şartlardan dolayı organizasyondaki senkronizasyon zorluğu farklı triyaj yaklaşımı ve uygulamalarına yol açmıştır (7).

Bu klasik triyaj şartlarından ayrılmanın yanında Alman Etik Konseyi yayınlamış olduğu tavsiye metninde triyajı 'ex-ante triyaj' ve 'ex-post triyaj' olmak üzere iki farklı senaryo doğrultusunda sınıflandırmıştır. Ex-ante triyaj dendiğinde mevcut yoğun bakım yatağı sayısının, bu yatağa ihtiyacı olan insan sayısindan daha az olduğu durumlarda yapılan triyaj kastedilmektedir. Ex-post triyaj ise bütün yatakların dolu olması durumunda, yoğun bakım tedavisine 
ihtiyacı olan bir hastanın hayatının ancak yoğun bakımdaki bir başka hastanın tedavisini sonlandırarak kurtarılabileceği durumda yapılan triyajdır (8). Expost triyaj, hukuki açıdan sorunlu, etik açıdan tartışmalı ve psikolojik olarak ağır sonuçları olabilecek bir uygulamadır (9). İngilizce literatürde ise ex-post triyaj, kaynakların durumuna dair her zaman net bir tanımlama yapılmaksızın başlanılmış tedavinin sonlandırılması, İngilizce "withdrawing” kavramı çerçevesinde tartışılmıştır $(10,11)$. İngiltere ise kaynakların doluluğunu temel alarak pandemiyi dört aşamada kategorize etmiş ve kırmızı kodlu son seviyeyi triyaj riskinin başladığı evre olarak tanımlamıştır. Bu son evrede kaynakların tamamen tükendiği kriz sürecindeki ex-post triyaj uygulamalarını "ters triyajı” (reverse triage) şeklinde isimlendirilmiştir (12).

\section{GEREÇ VE YÖNTEM}

Triyaj uygulamalarının Covid-19 Pandemisi sürecinde nasıl ve hangi ilkeler doğrultusunda yapılması gerektiği birçok ülkenin yetkili meslek örgütleri (Anesteziyoloji, Reanimasyon, Yoğun Bakım Dernekleri vd.) ve etik konseyleri tarafından tartışılmış ve triyaj uygulamalarına dair çeşitli rehberler ve tavsiye metinleri yayınlanmıştır. Bu çalışmada Almanya, Avusturya, Belçika, Fransa, İngiltere, İsviçre ve İtalya’nın yoğun bakım derneklerinin triyaj uygulamalarına dair yayınlamış olduğu rehberlerin içerikleri normatif analiz yöntemiyle araştırılmıştır. Ayrıca bu rehberlerin içeriklerinin operasyonel olarak uygulanabilirliği etik açıdan değerlendirilmiştir. $\mathrm{Bu}$ amaç doğrultusunda pandemi sürecinde meslek derneklerinin yayınladıkları rehberlerin uygulamadaki ve kavramsal arka plandaki mutabakat alanları tespit edilmiş ve konsensüs sağlanamayan ya da birbirine zıt uygulamalar ortaya konulmuştur

\section{BULGULAR}

Covid-19 pandemisinin Avrupa kıtasında ilk görülen vakalardan birkaç hafta sonra yukarıda ismi zikredilmiş olan ülkelerin anestezi, yoğun bakım ve acil tıp gibi dernekleri hızlıca triyaj rehberlerini yayınlamaya başlamıştır (13-18). Fransız Anestezi ve
Yoğun Bakım Derneği (SFAR) herhangi bir metin yayınlamayıp, İsviçre'nin yayınlamış olduğu rehberi internet sayfasından tavsiye olarak paylaştığı için, Fransa'ya ayrı bir başlıkta yer verilmemiştir (19). Fransa'nın Ulusal Etik Komitesi (CCNE) ise ağırlıklı olarak triyajı konu edinen, Covid-19 pandemisinde ortaya çıkacak etik problemler için genel bir tavsiye metni yayınlamıştır (20). İsviçre, Almanya ve İngiltere ise metinlerini ortalama bir ay sonra salgının gelişim sürecine göre ihtiyaçlar doğrultusunda yenilemiştir. Aynı amaç için yayınlanan rehberlerde içerik ve sistematik açısından farklılıklar tespit etmek mümkündür. Almanya, İngiltere ve İsviçre'nin rehberleri kapsamlı başlıklar ile öne çıkmaktadır. (Bkz. Tablo-1) Buna ek olarak Almanya ve İngiltere'nin rehberlerinde sağlık çalışanlarının sahada faydalanmaları ve karar vermede yardımcı olması amacıyla rehberde verilen tavsiyelerin uygulanmasına yönelik pratik dokümantasyonunu da ek olarak verilmiştir. Yayınlanan rehberlerden İsviçre ve İngiltere'nin rehberi resmî belge statüsünde olmakla birlikte, sadece İngiltere’nin metninin kurumsal bağlayıcıllğı bulunmaktadır (21). İsviçre’nin metni yönetmelik (Richtlinie) seviyesinde resmi bir belge olmasına karşın, kurumsal bağlayıcılığı bulunmamaktadır (17).

Rehberlerin içeriğinde ortak birçok nokta bulunmakla birlikte, farklılıklar hatta birbirine tamamen zit uygulama ve tavsiyeler de bulunmaktadır. Triyaj için hazırlıklı olma ve önceden belirlenmiş şeffaf kriterler doğrultusunda triyaj yapılması bütün rehberlerin temel ortak noktasidır. Triyaj hedefi ve triyajda kullanılacak kriterlerde ise ülkeler arasında ciddi farklılıklar, hatta tezatlıklar bulunmaktadır. Triyaj sürecinde, hasta tedaviye devam etmek istemediği halde, hastanın yoğun bakımda olmasını önlemek için, isteğinin her adımda öncelikli olarak sorgulanması bütün rehberlerde ortak olarak bulunmaktadır. Yine, tedavinin beyhudeliğinin (futility) tespiti için, prognoz ve tedavi hedefinin sürekli yeniden değerlendirilmesi de bir diğer ortak noktadır. Hastanın yaşının triyaj kriterleri arasında bulunup bulunmaması, bulunursa nasıl bir etkisinin olması ise rehberler arasındaki diğer bir tartışmalı alandır. Triyaj yapılırken belirli skalaların kullanılmasına ise 
Tablo 1. Triyaj rehberlerinin özet gösterimi

\begin{tabular}{|c|c|c|c|c|}
\hline Ülke adı & Yayınlayan Kurum & Tarih & Başlık & İçindekiler \\
\hline Almanya(13) & $\begin{array}{l}\text { Alman İnterdisipli- } \\
\text { ner Yoğun Bakım ve } \\
\text { Acil Tıp Derneği }\end{array}$ & $\begin{array}{c}25.03 .2020 \\
{ }^{\star} 17.04 .2020 \\
\text { (ikinci versiyon) }\end{array}$ & $\begin{array}{l}\text { Covid-19 Pandemisi } \\
\text { Bağlamında Yoğun } \\
\text { Bakım Kaynaklarının } \\
\text { Tahsisine İlişkin Ka- } \\
\text { rarlar }\end{array}$ & $\begin{array}{c}\text { 1. Arka Plan } \\
\text { 2. Kaynak Kitlığı Durumunda Ön- } \\
\text { celiklendirme Kararları İçin Genel } \\
\text { İlkeler } \\
\text { 3. Kaynak Kıtlığı Durumunda } \\
\text { Önceliklendirme Kararları İçin } \\
\text { Prosedür } \\
\text { 4. Sağlık Çalışanlarının Korunması- } \\
\text { na Yönelik Öneriler } \\
\text { • Literatür } \\
\text { • Metnin Yazımına Katkı Sağlayan } \\
\text { İsimler } \\
\text { • Karar Verme Algoritması } \\
\text { • Kararın Dokümantasyonu İçin } \\
\text { Yardım }\end{array}$ \\
\hline Avusturya(14) & $\begin{array}{c}\text { Anestezi, Reanimas- } \\
\text { yon ve Yoğun Bakım } \\
\text { Derneği }\end{array}$ & 17.03 .2020 & $\begin{array}{c}\text { Covid-19 Pandemisi } \\
\text { Sebebiyle Yoğun Ba- } \\
\text { kım Kaynaklarının } \\
\text { Tahsisi }\end{array}$ & $\begin{array}{c}\text { 1. Arka plan } \\
\text { 2. Tavsiyeler } \\
\text { 3. Etik İlkeler } \\
\text { Ek- Potansiyel Yoğun Bakım Has- } \\
\text { talarının Triyajı İçin Puanlama } \\
\text { Sistemi } \\
\end{array}$ \\
\hline Belçika(15) & $\begin{array}{c}\text { Belçika Yoğun Bakım } \\
\text { Derneği }\end{array}$ & 26.03 .2020 & $\begin{array}{l}2020 \text { Covid-19 Salgını } \\
\text { Sırasında Belçikadaki } \\
\text { Yoğun Bakımın Oran- } \\
\text { tılllığına İlişkin Etik } \\
\text { İlkeler: Belçika Yoğun } \\
\text { Bakım Derneğinin } \\
\text { Tavsiyesi }\end{array}$ & $\begin{array}{c}\text { 1. Giriş } \\
\text { 2. Covid-19: özel hususlar } \\
\text { 3. Belçika Yoğun Bakım Derneği'nin } \\
\text { Covid-19 Kritik Bakım etik öneri- } \\
\text { liler } \\
\text { I. Yoğun bakım ünitesine kabul } \\
\text { edilmeden önce gelişmiş bakım } \\
\text { planlaması } \\
\text { II. Hastane dışı kardiyopulmoner } \\
\text { resüsitasyon } \\
\text { III. Hastanede triyaj için etik hu- } \\
\text { suslar }\end{array}$ \\
\hline İngiltere(16) & $\begin{array}{l}\text { Yoğun Bakım Top- } \\
\text { luluğu }\end{array}$ & $\begin{array}{c}05.05 .2020 \\
\text { *28.05.2020 } \\
\text { (ikinci versiyon) }\end{array}$ & $\begin{array}{l}\text { Klinik Rehber: Co- } \\
\text { vid-19 Hastalarının } \\
\text { Kritik Bakımdan } \\
\text { Fayda Sağlayıp Sağla- } \\
\text { mayacağının Değer- } \\
\text { lendirmesi ve Kapa- } \\
\text { site Yetersizliklerinde } \\
\text { Objektif Bir Yaklaşım }\end{array}$ & $\begin{array}{c}\text { Özet } \\
\text { 1. İlkeler } \\
\text { 2. Yoğun Bakımın Ne Zaman Uygun } \\
\text { Bir Seçenek Olduğunu Belirlemek } \\
\text { İçin Yapılandırılmış Bir Yaklaşım } \\
\text { 3. Yoğun Bakım Kapasitesi ve Karar } \\
\text { Verme: Organizasyonel ve Bireysel } \\
\text { Sorumluluklar } \\
\text { 4. Yoğun Bakım Kapasitesinin Yeter- } \\
\text { sizliğinde Etik Uygulama (Yalnızca } \\
\text { CRITCON-PANDEMIC-4) } \\
\text { 5. Bu Rehberin Kullanımı } \\
\text { • Ek-1 Kapasite Yönetimi: CRIT- } \\
\text { CON-PANDEMIC Düzeyleri } \\
\text { • Ek-2 Covid-19 Karar Destek Yar- } \\
\text { dımı }\end{array}$ \\
\hline
\end{tabular}




\begin{tabular}{|c|c|c|c|c|}
\hline İsviçre(17) & $\begin{array}{l}\text { İsviçre Tıp Bilimleri } \\
\text { Akademisi } \\
\text { (Fransız Anestezi ve } \\
\text { Yoğun Bakım Der- } \\
\text { neği) }\end{array}$ & $\begin{array}{c}20.03 .2020 \\
{ }^{*} 24.03 .2020 \\
\text { (ikinci versiyon) } \\
{ }_{*}^{*} 04.11 .2020 \\
\text { (üçüncü versiyon) } \\
\\
(30.03 .2020) \\
\text { (Fransa'nın İsviç- } \\
\text { re’nin rehberini } \\
\text { yayınladığı tarih) }\end{array}$ & $\begin{array}{l}\text { Covid-19 Pandemisi: } \\
\text { Kaynakların Yetersiz } \\
\text { Olduğu Durumda } \\
\text { Yoğun Bakım Tedavi- } \\
\text { lerinin Triyajı }\end{array}$ & $\begin{array}{c}\text { 1. Arka Plan } \\
\text { 2. Yönerge } \\
\text { a. Yürürlük alanı } \\
\text { b. Temel Etik İlkeler } \\
\text { c. Kaynakların yetersizliği } \\
\text { durumunda yoğun bakım için triyaj } \\
\text { kriterleri } \\
\text { d. Triyaj kararları } \\
\text { e. Karar verme süreçleri } \\
\text { 3. Ekler- Literatür ve metnin } \\
\text { yazımında katkısı olanlar }\end{array}$ \\
\hline İtalya (18) & $\begin{array}{l}\text { Anestezi, Analjezi, } \\
\text { Resüsitasyon ve Yo- } \\
\text { ğun Bakım Derneği }\end{array}$ & 6 Mart 2020 & $\begin{array}{c}\text { Kaynakların Kısıt- } \\
\text { lı Olduğu İstisnai } \\
\text { Durumlarda Yoğun } \\
\text { Bakım Tedavilerinin } \\
\text { Dağıtımı İçin Tavsi- } \\
\text { yeler }\end{array}$ & $\begin{array}{l}\text { - Giriş } \\
\text { • Metot } \\
\text { Tavsiyeler }\end{array}$ \\
\hline
\end{tabular}

İtalya ve Belçika hariç diğer ülkelerin rehberlerinde yer verilmiştir. Covid-19 hastalarına ya da belirli bir sosyal gruba öncelik verilmesi ya da negatif ayrımcllık yapılması da yine rehberler arasındaki tartışmalı başlıklardandır. Bunun yanında rehberlerde triyaja ne zaman başlanılması gerektiği de tartışılmıştır.

Kaynakların tükenme durumunun tasnifine dair de farklı kategoriler yapılmıştır. Burada İngiltere’nin olağanüstü durumlar için önceden belirlemiş olduğu CRITCON Pandemi düzeyleri sistemi dikkat çekmektedir (12). Belçika hariç bütün metinlerde farklı yoğunlukta da olsa triyaja başlama seviyesi tanımlanmış ve sadece belirli hastane ya da bölgelerde kaynakların tükenmesi durumunda hastaların kaynakların tükenmediği bölgelere sevk edilmesi gerektiği belirtilmiştir. Bunun yanında ek olarak İngiltere ve İsviçre’nin rehberlerinde ikametgâhın asla ayrımcılık sebebi olamayacağı ve sevk zincirinin organizasyonunun önemi vurgulanmıştır. Triyaj sürecinin özellikle hekimler için yıpratıcı bir süreç olduğu ve hekimlerin bu süreçte psikolojik olarak desteklenmesi gerektiği rehberlerdeki bir diğer ortak nokta olduğu söylenebilir. Buna ek olarak diğer bir ortak nokta ise, triyaj sonrasi tedaviden mahrum birakılan hastanın, tedavisinin tamamen kesilmemesi ve mevcut olan tedavi ya da bakım imkânlarının sunulması gerektiğinin belirtilmesidir. Burada özellikle palyatif bakım imkânlarının sağlanması önem arz etmektedir. Bu genel değerlendirme doğrultusunda triyaj rehberlerindeki ihtilaflı başlıklar, tıbbi triyaj kriterlerinde kullanılan parametler, triyaj hedefi, yaş, bazı sosyal gruplara öncelik verilmesi, Covid-19 hastalarına özel uygulama ve «first come, first served» şeklinde belirlenmiştir. (Bkz. Tablo-2)

\section{Triyaj Rehberlerinde Kullanılan Tıbbi Kriterler}

Triyajda hastanın mevcut tıbbi durumunun triyaj kriteri olarak kullanılması bütün metinlerin ortak noktası olmakla birlikte hangi tıbbi parametrelerin kullanılacağı ve bunların ölçüm ve değerlendirilmesinin hangi araçlarla yapılacağ farklılık göstermektedir. Belirlenen tedavi hedefi doğrultusunda hastaya yarar sağlamayacak olan beyhude tedavinin (medical futility) önlenmesi amacryla endikasyonun olup olmamasının tespiti ve sonrasında hastanın prognozu genel olarak kabul edilen tıbbi kriterlerdir. Bununla birlikte morbidite Almanya, Avusturya, İngiltere ve İtalya’da triyaj kriteri olarak kabul edilmiştir. İtalya'da ise organ yetmezliğine de ayrı bir değerlendirme olarak yer verilirken, Almanya ve Avusturya'da Ardışık Organ Yetmezliği Değerlendirme Skorunun (Sequential Organ Failure Assessment Score: SOFA) kullanılması tavsiye edilmiştir. Hastanın genel durumunun değerlendirilmesi Belçika ve İtalya haricindeki ülkelerde Klinik Kırılganlık Ölçeği (Clinical Frailty Scale) kullanılarak belirlenmesi gerektiği belirtilmiştir.

Rehberlerde genel olarak skalaların kullanılma eğilimi olmasına rağmen, skala kullanımının bir stan- 


\begin{tabular}{|c|c|c|c|c|c|c|c|c|}
\hline 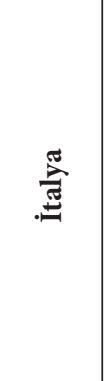 & 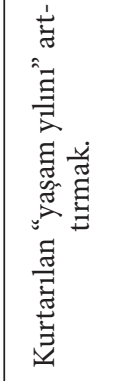 & 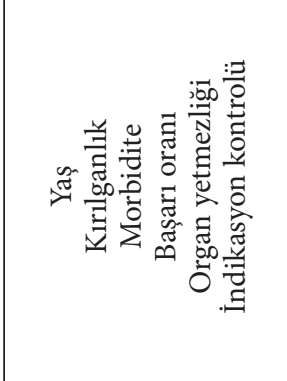 & & 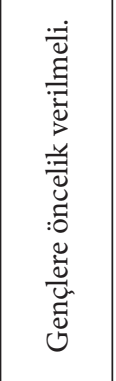 & 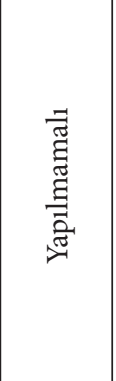 & 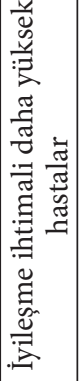 & 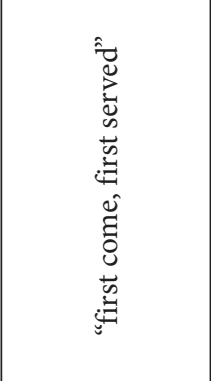 & 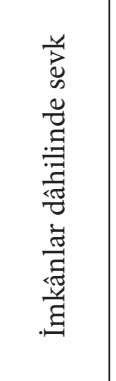 \\
\hline 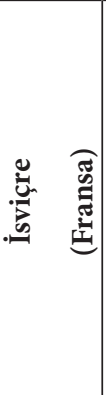 & 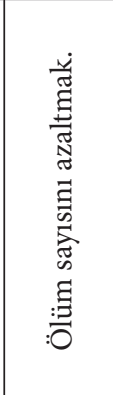 & 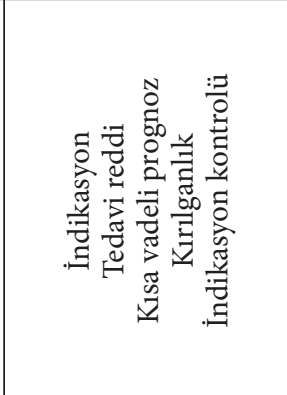 & 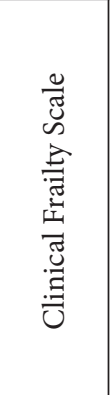 & 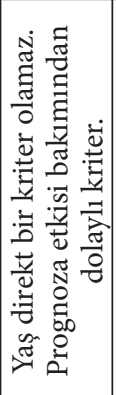 & 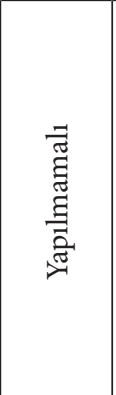 & & 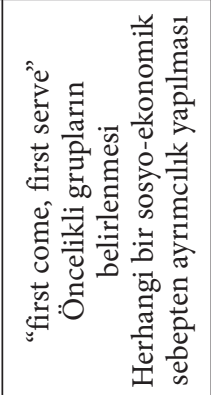 & 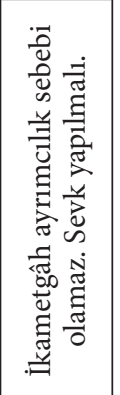 \\
\hline 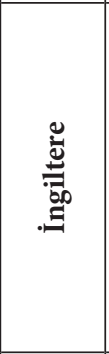 & 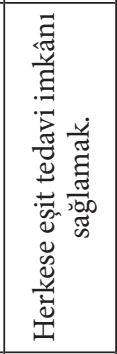 & 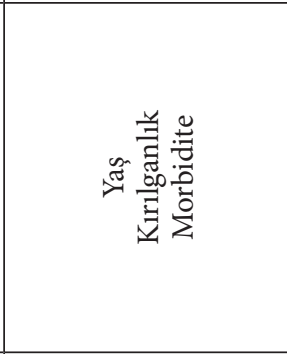 & 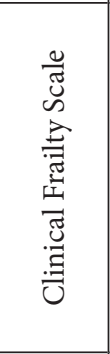 & 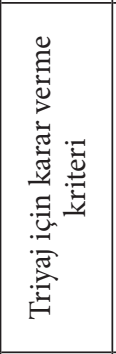 & 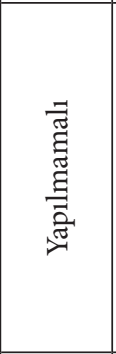 & & 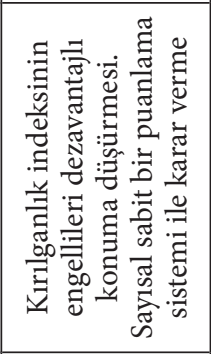 & 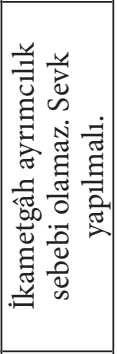 \\
\hline 氶 & 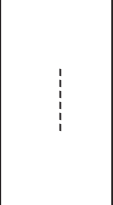 & 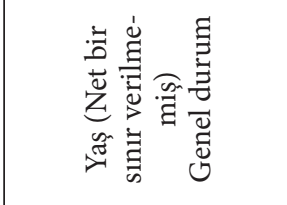 & & 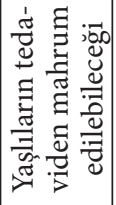 & 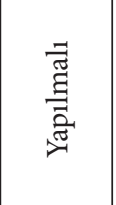 & & & \\
\hline 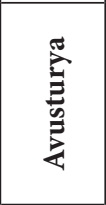 & 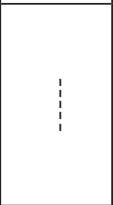 & 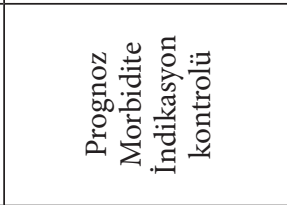 & 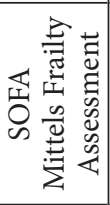 & 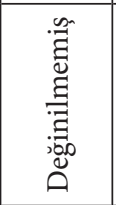 & 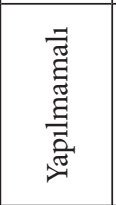 & 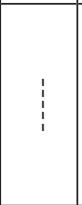 & 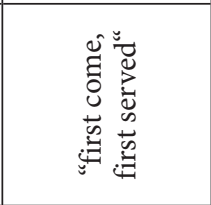 & 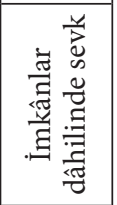 \\
\hline 蔭 & 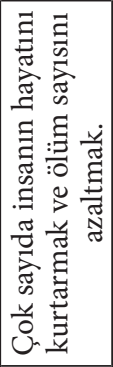 & 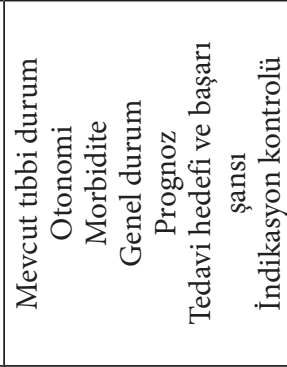 & 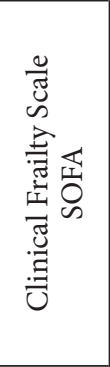 & 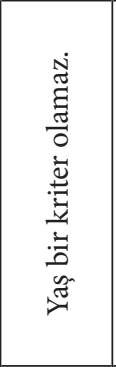 & 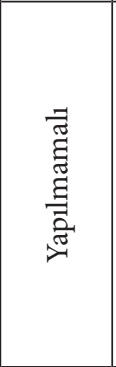 & 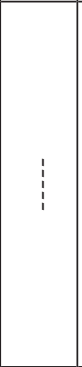 & 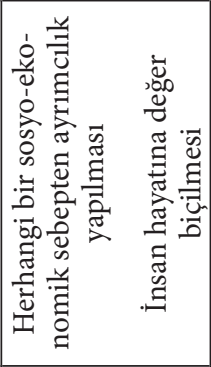 & 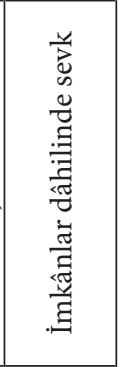 \\
\hline & 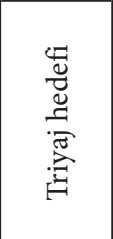 & 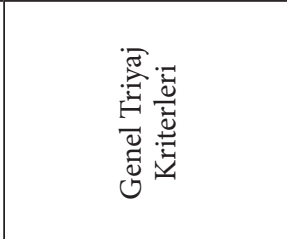 & 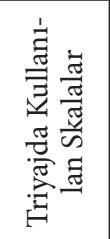 & 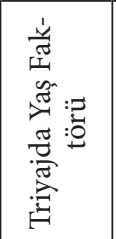 & 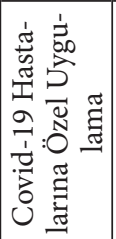 & 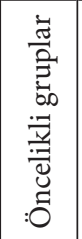 & 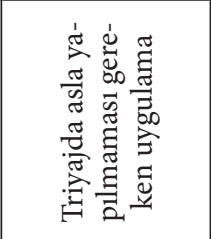 & 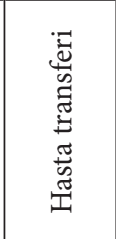 \\
\hline
\end{tabular}


dart olmaması ya da ülkeler arasında farklılıklar göstermesi de triyajın tıbbi olarak değerlendirilmesinde de bir mutabakat olmadığını göstermektedir. Prognozu en iyi olanın önceliklendirilmesi, triyaj için en sık yapılan tavsiye olmakla birlikte, prognozun nasıl ve hangi kriterler doğrultusunda somutlaştırılacağ ve hekimleri baskı altına almaksızın nasıl adil bir karar verme sistemi olușturulacağı tartışmalı bir alan olarak kalmaktadır (22). ABD'de bazı kurumların tavsiye ettiği gibi belirli hastalıklara sahip olanların, örneğin böbrek yetmezliği ya da ileri seviyede kalp yetmezliği gibi, pandemi süresince yoğun bakıma alınmaması gibi kararlar, bu hastalık gruplarındaki kişilere karşı ayrımcılığa sebep olduğu ve dinamik bir karar verme süreci sağlamadığı için etik açıdan problemli olarak değerlendirilmiştir (23).

\section{Triyaj Hedefi: Kurtarılacak İnsan Ha- yatı Sayısı versus Kurtarılacak Yaşam Yılı Sayısı}

Triyaj hedefleri metinlerin hepsinde açık bir şekilde belirtilmemekle birlikte, çok sayıda insan hayatı kurtarmak ve en fazla yaşam yılını kazanmak iki ana hedef olarak karşımıza çıkmaktadır. Almanya, Avusturya ve İsviçre kurtarılan yaşam yılına dikkat edilmeksizin, özellikle tıbbi kriterler çerçevesinde yapılan triyaj uygulamaları ile ölüm oranlarının azaltılmasını ve çok sayıda insan hayatının kurtarılmasını hedeflemektedirler. Buna karşın Belçika ve İtalya utilitaryan olarak adlandırabileceğimiz bir tavır ile en fazla yaşam yılının kurtarılmasını hedef olarak benimsemiştir. İngiltere'nin rehberinde ise, rehberin hedefinin herkese eşit tıbbi uygulama sağlamak olduğu belirtmekle birlikte net bir triyaj hedefine metinde yer vermemiştir. Ama triyaj kriterleri içerisinde yaşın direkt bir kriter olarak bulunmasından dolayı, İngiltere'nin de kurtarılacak yaşam yılının arttırılmasını hedeflediği tespiti yapılabilir. Yaşın direkt bir triyaj kriteri olamayacağı Almanya ve İsviçre’nin metninde açıkça belirtilmişken, Avusturya'nın metninde buna dair bir uyarı bulunmamaktadır. Burada en çok sayıda insanın hayatını kurtarma hedefinin, utilitarist bir yaklaşım şeklinde anlaşılmaması gerektiği önemlidir (24). Olağanüstü koşullarda bile hastanın yaşından ya da başka belirlenen sabit bir kriterden dolayı ölümünün hedeflenemeyeceği ve zorunlu olarak uygulanması gereken bir önceliklendirme sisteminin genel amacının tüm ölüm ve hastalık oranlarını en aza indirmek olması gerektiği belirtilmiştir $(6,25,26)$.

\section{Yaş}

Triyaj uygulamalarında hastanın yaşının nasıl bir rol oynaması gerektiği konusunda farklı ülkelerin rehberlerinde önemli farklılıklar görülmekte ve yaş oldukça tartışmalı bir kriter olarak karşımıza çıkmaktadır. Belçika ve İtalya gençlerin beklenen yaşam yıllarının daha fazla olduğu için, yaşlıların kaynakların yetersiz olduğu bir durumda gençler karşısında tedaviden mahrum bırakılabileceğini söylemiştir. Ancak İtalya'da yaş direkt bir kriterken, Belçika'da ise sadece yaşlı bakım evinde kalanların yoğun bakıma sevk edilmeyebileceğini belirtilmiştir. İngiltere’nin rehberinde ise, Klinik Kırılganlık Ölçeği ve morbidite puanlamasının yanında hastanın yaşı da direkt olarak triyaj algoritmasına dâhil edilmiştir. Ancak İngiliz Tabipler Birliği'nin yayınlamış olduğu Covid-19 rehberinde genç hastalara irticalen öncelik verilmemesine dair uyarı bulunmaktadır.(11) Almanyảnın metninde ise yaşın asla bir kriter olarak kullanılamayacağı yer almaktadır. İsviçre’nin metninde ise yaşın direkt bir kriter olamayacağı uyarısının yanında prognoza etkisi bakımından dolaylı bir kriter olması gerektiği belirtilmiştir. Avusturya’nın rehberinde ise hastanın yaşının triyaja etkisi bağlamında herhangi bir açıklama bulunmamaktadır.

Bu tartışmalar ve sunulan etik argümanlar sonucunda, yaşın triyajda bir kriter olarak kullanılması gerektiğini savunanlar genel olarak gençlere nispeten yaşlıların daha fazla "kaynak tüketen" bir grup olduğunu ve triyajda temel ilkenin en fazla insan için faydaları en üst düzeye çıkarmak olduğu için iyileşme potansiyeli daha çok olan ve tedavisi daha kısa sürecek olan gençlerin yaşlıların karşısında önceliklendirilmesi gerektiğini savunmaktadırlar.(18) Utilitarist görüş çerçevesinde ise, aynı durumdaki yaşlı ve genç hasta arasında seçim yapmak zorunda kalındığında, iyileştikten sonraki yaşam beklentisi daha fazla ol- 
duğu için genç hastanın önceliklendirilmesi gerekmektedir (22). ABD'deki bazı eyaletlerin rehberlerinde ise yaşam döngüsü ilkesi (the life cycle principle) doğrultusunda tamamen aynı durumda olan genç ve yaşlı hasta arasında kalındığında, genç hastaya tedavi imkânı sağlanması gerektiği tavsiye edilmiştir. Yaşam döngüsü ilkesinin etik temellendirilmesi her bir bireyin çocukluk, gençlik, yetişkinlik ve yaşlılık döngüsünden geçebilmesi için eşit firsatın verilmesi gerektiği argümanına dayanmaktadır $(23,27)$. Buradaki önceliklendirme bireyin gelecekteki sosyal faydasına ya da hayatının değerine dayanmaz. Genç bireyler, hayatın evrelerinin daha azını tecrübe ettiği için ve bu evreleri yaşamak için daha az firsata sahip olduklarından dolayı bu yaşamın evrelerini daha fazla tecrübe edenler karşısında öncelikli konuma getirilirler (28). Bu bağlamda etik argüman olarak her ne kadar benzeri sonuçlara ulaşsalar bile utilitaryan yaklaşım ve yaşam döngüsü karakter ve çıkış noktası olarak birbirinden ayrılırlar.

Yaşın direkt bir kriter olarak kullanılamayacağ 1 ama yaşla birlikte kırılganlığın ve çoklu organ yetmezliğine girme ihtimalinin artma ihtimalinin göz ardı edilemeyeceğini belirten ve yaşı direkt bir tıbbi kriter olarak almayıp, yaşın tıbbi duruma etkisi bağlamında değerlendirilmesi gerektiğini savunanlar da bulunmaktadır $(17,29)$. Bunun yanında yaşın sadece tedavinin başarı şansını hesaplamada kullanılması gerektiği görüşünü benimseyenler de bulunmaktadır (22). Bu durumda, hastanın tıbbi durumu merkeze alınıp kategorik bir kriter olarak kabul edilirken, yaş hastanın hastalığına ve genel durumuna etkisi bakımından değerlendirmeye alınan hipotetik bir kriter olmaktadır (30). Yaşlı insanların kolay incinebilen grubun içerisinde bulundukları için herhangi bir adaletsizlik ve tedaviden mahrum birakma durumundan özellikle korunması gerektiği de savunulmuştur (8).

\section{Bazı Sosyal Gruplara Öncelik Verilmesi}

İncelenen rehberlerde herhangi bir sosyal grubun önceliklendirilmesi tavsiyesi bulunmamakla birlikte, Almanya ve İsviçre'nin metninde ise yapılmamasına dair uyarı bulunmaktadır. Bunun yanında, İtalya’nın rehberinde, triyajdaki en temel ilkenin en fazla insan için faydayı en üst düzeye çıkarmak amacıyla iyileşme potansiyeli daha çok olan ve tedavisi daha kısa sürecek olan gençlerin öncelikli bir grup olması gerektiği belirtilmiştir. ABD'de ise dört eyalet hamileleri, üç eyalet sağlık çalışanlarını ve bir tanesi ise gençleri öncelikli grup olarak tanımlamıştır (10). Sağlık çalışanlarının önceliklendirilmesi, bu bireylerin özünde daha değerli oldukları için değil, başkalarını kurtarmadaki 'araçsal değerlerine' dayandırılmaktadır. Bunun yanı sıra, sağlık personelinin başkalarına yardım etmek için kendilerini riske atmasının bir karşıllı̆̆ olarak da kabul edilebilir (23). Sağlık çalışanlarının öncelikli grup olarak tanımlanması, kendi hastalanma risklerinden endişe eden sağlık çalışanlarının kaygılarını azaltabilir (10). Bunlara ek olarak kolay incinebilir grup içerisinde bulunan insanların zarara uğramaması için önceliklendirilmesi gerektiği görüşü de literatürde tartışılmaktadır (26).

\section{Covid-19 Hastalarına Pozitif / Negatif Ayrımcılık}

Hazırlanan rehberler her ne kadar Covid-19 Pandemisindeki kaynakların kısıtlı olduğu ya da tükendiği durumlar için olsa da yapılacak uygulamalarda yoğun bakımdaki Covid-19 hastası olan ya da olmayan bütün hastaları kapsadığını unutmamak gerekir. Bununla birlikte Belçika hariç tüm rehberlerde Covid-19 hastalarına pozitif ya da negatif ayrımcılı̆̆a sebep olabilecek herhangi bir uygulama yapılmaması gerektiği uyarısı bulunmaktadır. Belçika ise bu konuda farklı bir tavır takınıp, Covid-19 hastalarına, gerekli bulaşma önlemleri sağlanmadığında sağlık personelini korumak adına reanimasyon yapılmamasını tavsiye etmiştir. Özellikle salgının ilk başladığ̣ dönemde Covid-19 hastalığının tedavisi için çok kısıtlı bilgi olduğu için, Almanyảnın metninde Covid-19 hastalarının prognozunun belirlenmesindeki zorluğa ve kötü prognoz konusundaki işaretlerin dikkatli takip edilmesi gerektiği uyarısı yapılmıştır (13). Ayrica Covid-19'lu hastalarla ilgilenirken, Covid-19 olmayan hastaların varlığının unutulmaması gerektiği ve pandemi dolayısıyla diğer hastalık grup- 
larındaki kişilerin tedaviden mahrum bırakılmaması gerektiği de vurgulanmıştır (20).

\section{«First Come, First Served» (İk Gelen Alır)}

İlk gelen hastanın sağlık hizmeti almasına dayalı bir triyaj yöntemi ise sadece Belçika tarafından tavsiye edilmiştir. Almanya, Avusturya, İsviçre ve İtalyảnın rehberleri ise bu yöntemin asla kullanılmaması gerektiğine dair uyarıda bulunmaktadır. İngiltere’nin metninde ise konuya değinilmemiştir. Belçika, olağanüstü afet durumlarında, «first come, first served» ve "tesadüfilik (random)" en adil ve en doğru triyaj yöntemi olduğunu iddia etmektedir.

Ayrıca ayrımcılığı önlediği için de bu uygulamayı savunanlar bulunmaktadır. Örneğin, Almanya'daki Cam Kemik Hastalığı Derneği bu ilkenin hekimleri hastaları arasında seçim yapmak gibi zor kararlar vermek zorunda bırakmadığı, ahlaki baskı altına almadığı ve ayrımcılığın önünü tamamen kapattığı için bu uygulamayı desteklemektedir (31). Bununla birlikte bu görüşlere karşı çıkıp bu ilkenin asla uygulanmaması gerektiğini ve acil durumlarda bu ilkenin triyajda uygulandığı takdirde ölüm oranlarının artacağı ve her bir seçimin farklı bir adaletsizliğe yol açabileceğini iddia edenler de bulunmaktadır (32). İtalya ise yaşlılar konusundaki ayrımcı tavrını bu ilke bağlamında da sürdürüp, kaynakları daha çok tüketebilecek olan yaşlılara öncelik tanınabileceğine imkân sağladığı ve bunun kaynakların adaletsiz dağılımina sebep olacağından dolayı asla yapılmaması gerektiğini belirtmiştir. Tartışmalarda bu görüşün reddedilmesinde, her ne kadar kaos ortamlarında uygulanabilirliği kolay olsa dahi tedavinin daha faydalı olabileceği bir hastanın bundan mahrum kalabilmesini engelleme fikri yatmaktadır (33). 'Piyango' (random) yöntemi ise "ilk gelen ilk alır" yöntemi gibi farklı tartışmalara yol açmış ve eleştirilmiştir. Asla uygulanmaması gereken bir usul olarak görülse de aynı prognoza ve genel duruma sahip hastalar arasında öncelik belirlenmesi için kullanılabileceği ifade edilmiștir (34).

\section{TRIYAJ REHBERLERINDEKI NOR- MATIF KAVRAMLAR ve ETIK ILKE- LER}

Analiz edilen rehberlerde farklı normatif kavramlar kullanılmış ve kullanılan aynı kavramlardan da farklı çıkarımlar yapılmıştır. Diğer taraftan tıp etiğinde klasik olarak dört etik ilke olarak bilinen zarar vermeme, faydalı olma, hastanın özerkliği ve adalet ilkeleri de ya bazı rehberlerde yer almamış ya da fark11 vurgulamalarla tavsiyelere kaynak olarak gösterilmiştir. (Bkz. Tablo-3) Diğer taraftan rehberlerin teorik arka planı ve dokusu da birbirinden farklılıklar arz etmektedir. Örneğin Almanya ve İsviçre rehberlerinin, diğer ülkelerin yayınladıkları metinlere göre pandemi etiği kapsamındaki teorik çerçevesi daha güçlüdür. Belçika ve İtalyảnın metinleri ise etik argümanların verilmesi açısından ve teorik yönden daha zayıftır. Liberal düşünce geleneğine sahip ülkelerde otonomi/özerklik uygulamaları ön plana çıkarken, deontoloji geleneğinden gelen ülkelerde ise insanlık şerefi (İng. human dignity) etik normu ön plana çıkmaktadır. Şeffaflık ve güven kavramlarına yapılan vurgulamaların yoğunluğu farklı olsa da bütün metinlerde ortak normatif kavramlar olması dikkat çekmektedir.

Alman İnterdisipliner Yoğun Bakım ve Acil Tıp Derneği'nin yayınlamış olduğu triyaj rehberi incelendiğinde teorik bağlamda Alman Etik Konseyỉnin 27.3.2020 tarihinde yayınlamış olduğu tavsiye metnine (Stellungnahme) dayandığını tespit etmek mümkündür. Burada her ne kadar insanlık şerefi (Alm. Menschenwürde) somut olarak geçmese de bu kavramdan neşet eden bir tavır olan insan hayatına asla değer biçilemeyeceği vurgusu yapılmaktadır. Dolaysıyla tıpkı Alman Anayasası'nın temel etik normunda olduğu gibi bu rehber de insanlık şerefi kavramı üzerine bina edilmektedir. İngiltere'nin metninde ise her hastaya eşit tedavi imkânı sunulması üzerine bina edilmiş bir eşitlik vurgusu bulunmaktadır.

"Şeffaflı" ve "güven" etik değerleri rehberlerin en çok yer verdiği husus olmuştur. Yaşamının sonundaki hasta-hekim ilişkisi sırasında hekimin hastaya bilgi verirken şeffaf bir şekilde davranması tavsiye edilmiştir. Diğer taraftan ise triyaj uygulamalarında- 


\begin{tabular}{|c|c|c|c|c|c|c|c|c|}
\hline . & & 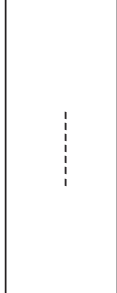 & 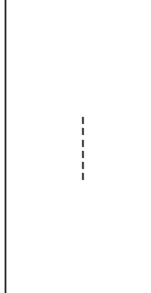 & & 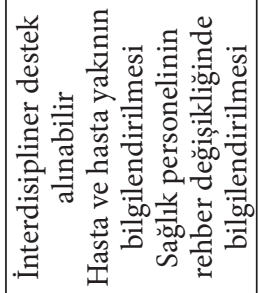 & 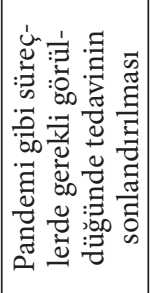 & i & i \\
\hline 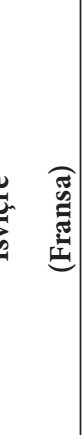 & & 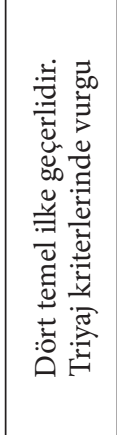 & 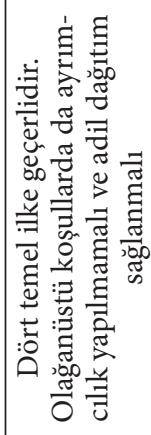 & & 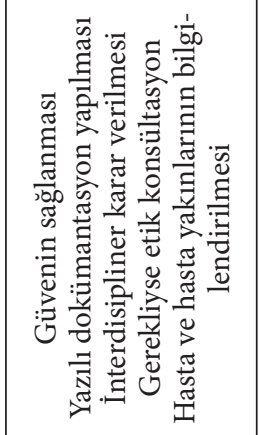 & & 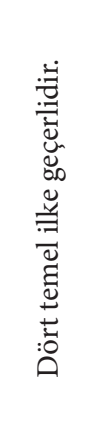 & 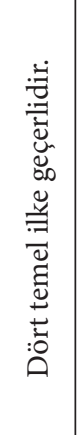 \\
\hline 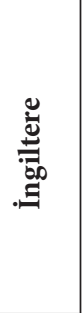 & & 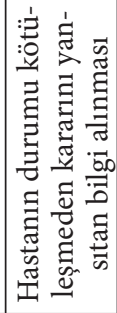 & 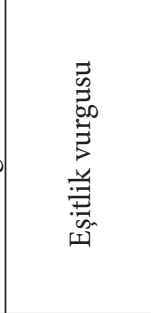 & 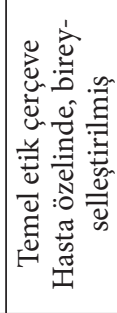 & 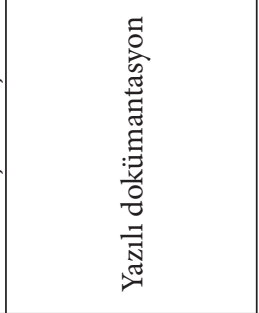 & & 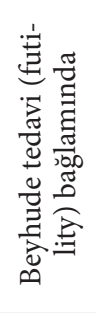 & 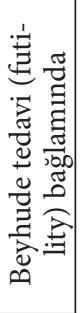 \\
\hline 离 & 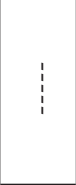 & 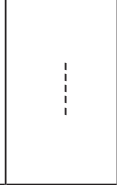 & 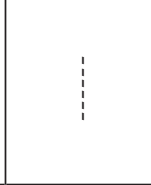 & & 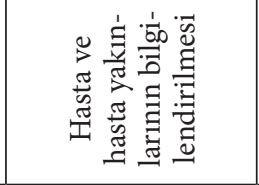 & & & 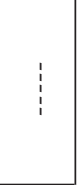 \\
\hline 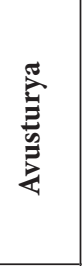 & & 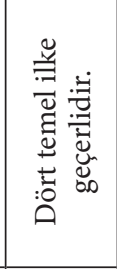 & 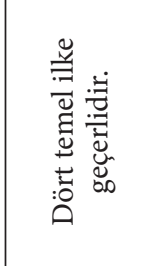 & & 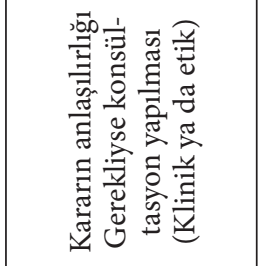 & 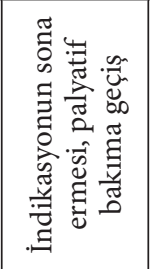 & 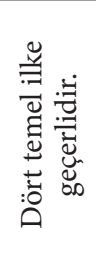 & 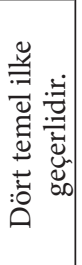 \\
\hline 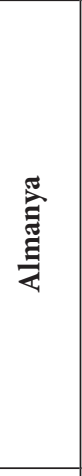 & 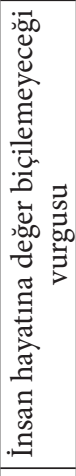 & 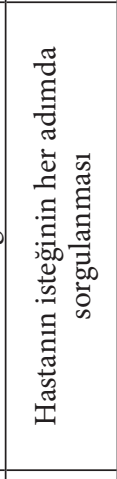 & 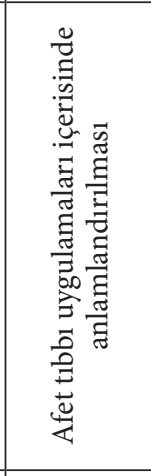 & & 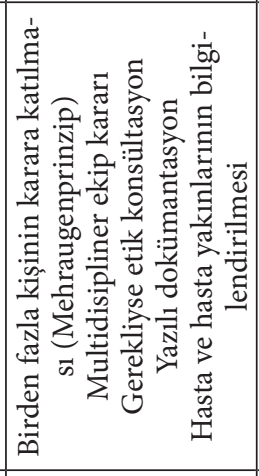 & 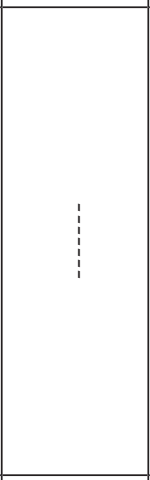 & & 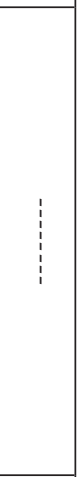 \\
\hline & 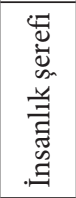 & $\begin{array}{l}\text { घี } \\
\text { : } \\
0 \\
0\end{array}$ & $\frac{\frac{\pi}{\pi}}{\frac{\pi}{4}}$ & 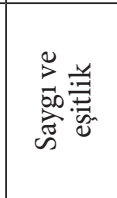 & 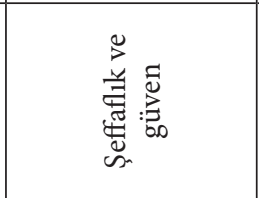 & $\begin{array}{l}\text { 当 } \\
\text { 䔍 } \\
\text { ○ }\end{array}$ & 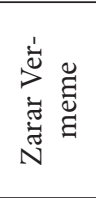 & 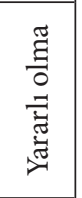 \\
\hline
\end{tabular}


ki kriterlerin de şeffaf olması ve bu konuda halkın da bilgilendirilmesi gerektiği vurgulanmıştır (26). Hatta süreçlerin sadece şeffaf yönetilmesini yeterli görmeyip, bu konuların kamuoyunun tartışmasına açılıp, bu tartışmalar sonucunda triyaj kriterlerinde gerekirse değişikliğe gidilmesi gerektiğini de iddia edenler bulunmaktadır (35). Nitekim Kanada Quebec Sağlik ve Sosyal Hizmetler derneği tarafından Mart 2020'de yayınlanan triyaj rehberinin ilk versiyonu, halkın itirazları ve yapılan anketler sonucunda revize edilip Kasım 2020’de tekrar yayınlamıştır (26). Bu uygulama kaos ortamında, halkı olup bitenler hakkında daha net bir bilgilendirme imkânı sunacağı gibi zor şartlarda çalışan sağlıkçıların karşılaşacağı tepkileri de azaltabilecektir.

Alman Etik Konseyi’nin yayınlamış olduğu tavsiye metninde ise eğer pandeminin başarılı bir şekilde yönetilebilmesi için halkın dayanışma içinde olması ve sorumlu davranması isteniyorsa her alanda şeffaflı̆̆ın sağlanması ve kamuoyunun doğru bilgilendirilmesinin gerektiği vurgulanmıştır (8). Benzer şekilde İngiltere merkezli Nuffield Biyoetik Konseyi ve Fransa Ulusal Etik Danışma Kurulu'nun yayınladığ 1 Covid-19 tavsiye metinlerinde de halkın yöneticilere güven duyması için, şeffaflı̆̆ın çok önemli olduğu vurgusu bulunmaktadır $(20,36)$. Etik kurumlar tarafından çizilen bu normatif çerçevenin, meslek örgütleri tarafından yayınlanan triyaj rehberleri için de belirleyici olduğu tespiti yapılabilir. Bu bağlamda triyaj süreçlerinde şeffaflık, sadece hasta-hekim ilişkisinin nasıl olması gerektiğine dair özerklik ilkesi kapsamında bir norm olmayıp, triyajın nasıl yapılacağının belirlenmesi ve sürecin nasıl işletilmesi gerektiğine dair standartların oluşturulmasını da içeren kapsamlı bir etik norm olarak karşımıza çıkmaktadır.

Özerklik (otonomi), zarar vermeme, faydalı olma ve adaletten oluşan dört temel etik prensibinin rehberlerde triyaj uygulamaları sırasında farklı şekillerde vurgulandığ 1 tespit edilmiştir. Normatif yönü zayıf olan Belçika ve İtalya’nın rehberlerinde, dört temel etik ilke bağlamında bir açılkama yer almazken, Avusturya pandemi sürecindeki triyaj uygulamalarında da dört temel etik ilkenin geçerli olduğunu belirtmiştir. Almanya, İngiltere ve İsviçre ise pande- mi şartlarında dört temel ilkenin uygulanmasının ancak pandeminin getirdiği olağanüstü şartlar göz önüne alınarak yeniden yorumlanmasıyla mümkün olacağını söylemişlerdir. Bu bağlamda en çok tartışılan ilke "adalet" kavramı olmuştur. İlkenin hangi adalet kuramı doğrultusunda anlamlandırıldığı ülkelere göre değişiklik göstermektedir. Örneğin İngiltere'de "eşitlik" vurgusu yapılırken İsviçre'de ise ayrımcılık yapılmaması gerektiği vurgulanmıştır. Almanya'nın rehberinde ise adalet kavramının afet tıbbı uygulamaları içerisinde anlamlandırılması gerektiği belirtilmiștir. Zarar vermeme ve yararlı olma ilkelerine Almanya’nın metninde değinilmezken, İsviçre'nin metninde pandemi koşullarında da bu ilkelerin geçerli olduğu belirtilmiştir. İngiltere’nin rehberinde ise, bu ilkelerin ancak beyhude (futility) tedavi bağlamında kullanılabileceği vurgulanmıştır. Burada triyaj uygulamalarında kaynakların kısıtlı olmasindan dolayı beyhude tedavinin, normal zamanlara kıyasla daha ciddi normatif bir anlamı olduğu söylenebilir. Kaynakların kısıtlı olduğu durumlarda, endikasyon olmaksızın tedaviye devam edildiği beyhudelik durumlarında, başka hastaların endikasyon olduğu halde triyaj sonrası tedaviden mahrum edilme ihtimali söz konusu olabilir. Bu bağlamda triyaj süreçlerinde endikasyonun devam edip etmediğinin sorgulanması rehberlerin ortak vurguladığı bir noktadır. Ama sadece İngiltere’nin rehberinde bu durum yararlı olma ve zarar vermeme etik ilkeleri bağlamında tartışılmıştır. Her ne kadar her ilke ve kavram herhangi bir şekilde tartışmalara konu olmuş olsa da pratik uygulamalar söz konusu olduğunda ilkelerin birbirinden bağımsız bir şekilde ele alınamayacağı aksine iç içe hareket ettikleri unutulmamalıdır.

\section{TARTIŞMA}

Covid-19 Salgınından dolayı 2020 yılının mart ayında bazı Avrupa ülkelerinde Covid-19 vakaları hızlı bir şekilde artmış ve buna paralel olarak yoğun bakım ünitelerinde de doluluk oranları yükselmiştir. Bazı hastaneler yoğun bakıma ihtiyacı olan tüm hastalara hizmet verememe durumuyla karşı karşıya kaldıklarından dolayı acil durumlarda kaynakların 
adil olarak dağıtılmasını içeren triyajla ilgili kıstasların tartışılması ve bir an önce yayınlanması gerekli olmuştur. İtalya ve İspanya gibi bu tür sorunları bizzat yaşayan ülkelerin yanında Almanya, Avusturya, İsviçre gibi bu sorunu henüz yaşamamış fakat karşılaşma ihtimali yüksek olan ülkeler de acilen yoğun bakım triyajı ile ilgili etik rehberleri oluşturmuştur. Bu hızlı oluşum sürecini incelediğimizde başta sağlık çalışanları olma üzere, hasta hakları dernekleri, hukukçular, siyasiler, diğer ilgili kurum ve kişilerin yanında etikçilerin de bu oluşuma aktif katkı sunduklarını görüyoruz (21). Literatürde rehberlerle ilgili bizden önce farklı kategoriler doğrultusunda yapılmış incelemeler bulunmakla birlikte, farklılıkların normatif analizini ve teorik arka plandaki etik norm ve ilkelerin tahlilini içeren bir çalışma bulunmamaktadır $(9,37)$.

Yukarıda ayrıntılarıyla analiz edilen kavram ve kıstaslar iki ana başlık altında sınıflandırılabilirler. Bunlardan birincisi genel kriterler diyebileceğimiz hastanın tıbbi veya biyolojik özellikler altında inceleyebileceğimiz yaş, hastalığın durumu, seyri, ölüm ihtimali gibi kriterleri içerirken, diğer grupta ise etik prensipler ve normatif kavramlar bulunmaktadır. Her ne kadar bu kıstas ve normatif kavramlar hazırlamış olduğumuz tablolarda ayrı ayrı ele alınmış olsalar bile aralarındaki sınırlar muğlak ve geçişken olup birbirleriyle ilişki içerisindedir.

Yukarıda analiz edilen triyaj rehberleri zor şartlarda ve zaman baskısı altında çalışan hekimler ve sağlık çalışanları için bir etik oryantasyon sağlamaktadır. Aynı zamanda Covid-19 hastalığı ile ilgili bilimsel ve şahsi tecrübeler hala yetersiz olduğu için hukuki açıdan da güvenli bir çalışma alanı açmaktadır. Yine bu rehberler karar süreçleri zor ve karmaşık vakalarda ekip tartışmalarında yol gösterici olmaktadır. Diğer taraftan bu rehberler ülke genelinde uygulanacağından keyfi, sübjektif ve izafi birtakım uygulamaların önüne geçecek, ortalama ve minimum bir etik standart her hastanede sağlanacaktır. Kıstas alınan kriterlerin tüm ülke düzeyinde aynı olması hastane nakillerini kolaylaştıracak ve hastaların fark11 hastanelerde farklı muamelelere uğramasını engellenecektir. Yine rehberlerde tavsiye edilen hasta ya- kınlarının mümkün olduğunca karar süreçlerine dâhil edilmesi, onların her aşamada bilgilendirilmesi şeffaf bir tedavi sürecinin yürütülmesine yol açacak ve bu da hasta yakınlarıyla iletişimin kalitesini arttıraraktır. Hasta yakınlarının memnuniyetinin yükselmesi ise onlarla iş birliğini kolaylaştıracak ve onlarla yaşanacak şiddet olayları da dâhil olmak üzere fark1 sorunları ve etik çatışmaları azaltacaktır.

Birçok etik rehberde tavsiye edilen özellikle zor karar verilecek vakalarda çok katılımlı bir tedavi ekibinin tartışarak ortak bir karar vermesi bir taraftan hekimin omuzlarında hissettiği sorumluluğu azaltacak, diğer taraftan ise vakalara yaklaşımdaki sübjektifliği azaltarak daha rasyonel kararları mümkün kılacaktır. Yine böylesi zor süreçlerde hastane etik kurulların etik danışmanlık hizmeti vermesi istenilen, tedavi ve bakım kalitesini arttıracak yardımcı bir hizmettir.

İncelenen etik rehberlerde öne çıan diğer bir husus ise yoğun bakım hizmeti verilemeyen hastaların yalnız bırakılmaması, ömrünün kalan kısımlarında palyatif tıbbın imkanlarının koordineli bir şekilde sunulması gerektiğidir. Özellikle başlanılmış tedavilerin sonlandirılması durumunda, eylemin yıkıcı duygusal etkilerini azaltmak için mutlaka palyatif bakım verilmesi tavsiye edilmiştir (23). Bu hastanın acılar içinde kendini yalnız hissetmesini engelleyecek, korku ve endişe içinde kalmamasını sağlayacaktır. Çünkü triyaj sonucunda yoğun bakım tedavisinden mahrum olmak demek, diğer tedavilerin ve bakımların kesileceği anlamına gelmemektedir (32).

$\mathrm{Bu}$ araştırma çerçevesinde yapılan incelemeler sırasında triyaj için hazırlanan klinik-etik rehberlerin yukarıda tartışılan olumlu yönlerinin yanında eleştirilmesi gereken yönleri de bulunmaktadır. Karşılaşılan sorun her ne kadar aynı karakterde olsa bile rehberlerin strüktüründe, genel kriterlerin içeriklerinde, kullanilan normatif kavramlarda, bu kavram ve etik prensiplerin önceliklendirilmesinde detayl bir şekilde açıkladığımız ve hazırladığımız tablolarda özetlediğimiz farklılıklar görülmektedir. Bu farkl1lıklar ilk etapta şaşkınlık yaratsa bile, bu rehberlerin ortaya çıktığı ülkenin sosyo-ekonomik şartları, özel 
tarihi, felsefi ve düşünce geleneği bu farklılıklar da şüphesiz rol oynamaktadır. Hatta aynı ülkede bile farklı kurumların yayınladıkları triyaj rehberlerinde birbirine muhalif tavsiyeler bulunabilmektedir. Örneğin Almanya Cam Kemik Hastalığı Derneği ülke içerisinde diğer rehberlerde reddedilen «First come, first served» yaklaşımını kabul eden bir tavır almıştır. Bu da demokrasi kültürünün yerleşmiş olduğu ülkelerde -pratik hayatta birtakım zorlukları olsa bile- bu tür çok sesliliğin tabii bir durum olarak algılanması gerektiğini göstermektedir. Burada detaylı incelemeye almadığımız fakat zaman zaman atıfta bulunduğumuz $\mathrm{ABD}$ gibi ülkelerde ise eyaletlere göre triyaj kriterleri değişebilmektedir. Bu da bir eyalette yoğun bakım hizmetlerinden yararlanabilecek bir kişinin, diğer bir eyalette aynı sağlık hizmetini alamama ihtimalini doğurmaktadır. Bu durum ise aynı ülkede farklı 'adalet standartlarının' olması gibi sorunlu bir durumu ortaya çıkarmaktadır.

Yukarıda analiz edilen etik rehberler ülkemiz açısından birçok önemli sonuçlar içermektedir. Covid-19 Pandemisinin çok yoğun olduğu dönemlerde mikro seviyedeki yoğun bakım hizmetlerinde dramatik olmasa bile triyaj şartları oluşmuştur. Zamanında ve hızlı bir şekilde hastanelerin genel yapısında ve yoğun bakım servislerinde yapılan değişiklikler ve organizasyonlarla belki İtalya ve İspanya'da ortaya çıkan dramatik sahneler istisnalar dışında yaşanmamıştır. Ancak elektif olan tedavi ve ameliyatların ertelenmesi sayesinde ve Covid-19 hastalarının dolaylı olarak öncelliklendirilmesiyle bu zor durum idare edilebilmiştir.

Yukarıdaki rehber analizlerinden elde edilenler bize etik tartışmalarda kullanılan 'etiğin evrenselliği' konusunda da bazı önemli sonuçlar ortaya koymaktadır. Özellikle uygulamalı ya da pratik etik (İng. applied ethics, Alm. praktische Ethik) alanında aynı etik sorun alanında hem farklı normatif kavramların kullanılması hem bu kavramlardan farklı davranış şekillerinin devşirilmesi, hem de farklı uygulamaların etik perspektiften tavsiye edilmesi bu tür teorik tartışmalarda ifade edilen 'etik evrenseldir' tezini çürütmektedir. Dolayısıyla normatif kavramlar da argüman haline getirilirken ve yorumlanırken o kişi ve kültürün temel dinamiklerinden etkilenmekte ve yukarıdaki analizimizde görüldüğü gibi farklı sonuçlar ortaya çıabilmektedir.

\section{SONUÇ ve TAVSIYYELER}

Yukarıda Covid-19 Pandemisi sürecinde yoğun bakım kaynaklarının yetersiz kalmasından dolayı verilen sağlık hizmetlerinin adil bir şekilde gerçekleştirilmesi için farklı Avrupa ülkelerinde hazırlanan triyaj rehberleri analitik ve eleştirel bir yaklaşımla incelenmiştir. Bu rehberlerdeki ortak amaç olağanüstü bir tıbbi durumda yoğun bakım kaynaklarının yetersiz kalması halinde mevcut kaynakların adil bir şekilde dağıtılmasıdır. Farklı rehberlerde bazı normatif kavramların ortak kullanıldığını tespit etmek mümkünken, diğer taraftan da birbirinden ayrılan genel kriterler ve farklı normatif kavramların kullanıldığını görüyoruz. Dolayısıyla pratik uygulamalar için yapılan tavsiyeler birbirinden ayrılabilmekte, bazen de aynı rehberler gelen eleştiriler veya değişen şartlar doğrultusunda revize edilebilmektedir.

Ülkemizde ise İtalya ve İspanya’nın yaşadığı gibi tecrübeler yaşanmamış olsa bile mikro düzeyde triyaj gerektiren vakalar ve durumlar ortaya çıkmıştır. Fakat ne Almanya gibi bir etik konseyin 'normatif çerçeve'yi belirleyen bir bildirisi, ne de ilgili meslek örgütlerinin veya Sağlık Bakanlığı’nın triyaj için bir etik rehber çalışması olmamıştır. Yukarıda açıkladığımız gerekçelerden dolayı bir 'etik vakum'un oluşmaması için ülkemizde de böylesi rehberlere ihtiyaç duyulmaktadır. Bu tür rehberler bazı Avrupa örneklerinde olduğu gibi disiplinler arası bir yaklaşımla, eleştiri ve tartışmaya açık, şeffaf bir süreçte hazırlanmalıdır.

Yukarıda araştırmamızın sonunda ulaşmış olduğumuz tespit ve sonuçların ışığında aşağıdaki tavsiyeler yapilabilir:

1. Covid-19 Pandemisinin farklı dönemleri göz önüne alındığında ülkemizde de 'etik triyaj rehberlerine' ihtiyaç duyulduğu tecrübesi ortaya çıkmıştır. Bunun için triyaj gerektiren herhangi bir sağlik sorununda acilen rehberler hazırlanmalıdır. Bu rehberlerin içerisindeki tavsiyeler arzu edilebilir, ekonomik açıdan gerçekçi, hukuken meşru, ahlaki argümanlarla savunulabilir ve etik açıdan gerekçelendiri- 
lebilir olmalıdır.

2. Bu rehberler Avrupa örneğinde görüldüğü gibi gerekli uzmanların yer aldığı multidisipliner ekipler tarafından, eleştiriye açık ve şeffaf bir süreç içerisinde ortaya konulmalıdır. Şartlar değiştiğinde, önemli hatalı noktalar tespit edildiğinde veya anlamlı ve değerli eleştiriler geldiğinde kısa bir süre içerisinde revize edilebilmelidir.

3. Mevcut kaynaklara göre triyajın belirlenmesi her ne kadar anlamlı ve doğru olsa bile Covid-19 tecrübesinden sonra böylesi durumların ortaya çıkabileceği ihtimalinden hareketle yoğun bakıma ayrılan kaynaklar farklı parametreleri gözeterek tekrar değerlendirilmelidir. Bilimsel veriler ve yapılan modellemeler doğrultusunda, yoğun bakım ihtiyaçları sadece normal süreçteki ihtiyacı karşılayacak şekilde değil, olağanüstü durumlarda da sağllk hizmetinin devamlılığını sağlamaya uyum sağlayacak şekilde tasarlanmalıdır.

4. Sadece normal süreçteki ekonomik kaygılar değil, olağanüstü durumlardaki kaynakların yetersiz kalmasından dolayı ortaya çıabilecek sosyo-kültürel, ekonomik, hukuki ve etik problemlerin muhtemel sonuçları da değerlendirilmeye alınmalıdır. Bu da sağlık alanında birtakım planlamalar yapılırken sadece ekonomik parametrelere indirgenmiş bir yaklaşımdan ziyade temel ahlaki ilkelerin göz önünde bulundurulmasını gerektirir.

5. Hekimlerin ve tüm sağlık çalışanların bu tür zorlu durumlarda etik analiz yaparak kararlara ulaşması oldukça karmaşık ve zor bir süreçtir. Dolayısıyla pandemi süreçleri ile ilgili etik konular sağlık çalışanlarının lisans ve lisansüstü eğitimlerinde yer almalıdır. Özellikle vaka analizine dayanan eğitim programları geliştirilerek, bu eğitim dallarında yaygınlaştırılmalıdır. Aynı bilgi ve karar verme becerileri daha hızlı bir şekilde hizmet içi eğitimlerle sahada çalışanlara aktarılmalıdır.

6. Beklenmeyen ve ani triyaj durumlarında (Avrupa'daki hastanelerde oldukça yaygın bir şekilde faaliyet gösteren) 'Hastane Etik Kurulları’ etkili olabilir. Bu kurulların fonksiyonu etik ikilem ve sorunlarda danışmanlık hizmeti vermektir. Bu kurullardan yeterli ve verimli bir şekilde yararlanabilmek için bu kurullar ülkemizdeki hastaneleri de yaygınlaştırılmalı ve mevcut olanlar aktif hale getirilmelidir.

7. Hastane etik kurullarının olmadığı durumlarda hızlı bir şekilde 'Etik Kriz Masası' oluşturulabilir ve karmaşık ve sorunlu karar alma süreçleri buradan yönetilebilir. Nitekim bazı hastanelerimizde (Örnek: İstanbul Tip Fakültesi) böylesi birimlerin oluşturulduğunu ve pandemi süreçlerinde çok verimli çalıştıkları tecrübe edilmiştir.

8. Pandemi sürecinde triyajlar yukarıdaki analizlerde de gösterildiği gibi pratik sorunların yanında birçok teorik sorunu da içermektedir. Yine bu sorunların çözümü ülkenin mevcut kültürel değerlerinden ve sosyo-ekonomik şartlarından bağımsız olarak gerçekleştirilemeyecektir. Bu şartların normatif ve pratik anlamı üzerine bilimsel çalışmalar yapılmalıdır. Bu çalışmalar için başta TÜBİTAK olmak üzere ülkemizdeki üniversite, bakanlıklar ve diğer kurum ve kuruluşlar kaynak ayırmalıdirlar.

9. Almanya örneğinde olduğu gibi Alman Etik Konseyỉnin hazırlamış olduğu daha çok normatif ve etik yönü ağır basan tavsiye metni daha sonra yapılacak metinlere ve tartışmalara önemli teorik bir zemin hazırlamış ve bu konuda oryantasyon sağlayarak çok önemli bir görev ifa etmiştir. Benzeri durumlarda aynı çalışmalara Türkiye'de de ihtiyaç olacağından ülkemizde de ilgili metinleri ortaya koyarak etik anlamda yol gösteren bir Etik Konseyi'ne ihtiyaç vardır.

Hakem Değerlendirmesi: Dış bağımsız.

Peer Review: Externally peer-reviewed.

Çalışma Konsepti/Tasarım E.A.; Veri ToplamaE.A., M.N.K.Ö.; Veri Analizi/Yorumlama- E.A., M.N.K.Ö,İ.İ.; Yazı Taslağı- E.A., M.N.K.Ö,İ.̇̇.; İçeriğin Eleştirel İncelemesi- E.A., M.N.K.Ö,İ.İ; Son Onay ve Sorumluluk- E.A., M.N.K.Ö,İ.İ.

Author Contributions: Conception/Design of Study- E.A.; Data Acquisition- E.A., M.N.K.Ö.; Data 
Analysis/Interpretation- E.A., M.N.K.Ö,İ.İ.; Drafting Manuscript- E.A., M.N.K.Ö,İ.̇.; Critical Revision of Manuscript- E.A., M.N.K.Ö,İ.I.; Final Approval and Accountability- E.A., M.N.K.Ö,İ.İ.

Çıkar Çatışması: Yazarlar çıkar çatışması beyan etmemişlerdir

Conflict of Interest: Authors declared no conflict of interest.

Finansal Destek: Bu çalışma İstanbul Üniversitesi Bilimsel Araştırma Projeleri Koordinasyon Birimi tarafından desteklenmiştir. Proje numarası: 36837, Proje Başlığı: Covid-19 Pandemisiyle Mücadelede Etik Sorunlar.

Financial Disclosure: This study was funded by Scientific Research Projects Coordination Unit of Istanbul University. Project number: 36837. Project title: Ethical Issues in Combating the Covid-19 Pandemic.

Teşekkür: Proje toplantılarında çalışmamıza görüş ve eleştirileriyle katkı sağlayan projenin danışma kurulu hocalarına hocalara ve çalıșma arkadaşlarımız Ayşenur Daldaban, Dr. Orhan Önder ve Tuğba Doğan’a teşekkür ederiz.

Acknowledgement: The authors would like to thank Ayşenur Daldaban, Dr. Orhan Önder and Tuğba Doğan for their important comments and critical perusal of this manuscript.

\section{KAYNAKLAR}

1. World Health Organization. Coronavirus (COVID-19) Dashboard 2021, [31.05.2021], Available from: https://covid19.who.int/.

2. İlkılıç İ. Covid-19 Sürecinde Etik Sorun Alanları. SD Sağlık Düşüncesi ve Tip Kültürü Dergisi. 2020;56:112-5.

3. Schaupp W, Kröll W, Ruckenbauereditor HW.editors. Bioethik in Wissenschaft und Gesellschaft. In: Lintner MM, Das TriageProblem in Italien während der COVID-19Pandemie. Nomos Verlagsgesellschaft $\mathrm{mbH} \&$ Co. KG.2020.p.87.

4. Centre National de Ressources Textuelles et Lexicales. CNDRTEL. Trier. Available from: https://www.cnrtl.fr/definition/triage.

5. Baker R, Strosberg M. Triage and equality: An historical reassessment of utilitarian analyses of triage. Kennedy Inst Ethics J. 1992;2(2):103-23.

6. Ellebrecht N. Triage. Charakteristika und Gegenwart eines ordnungsstiftenden Verfahrens.
Sociologia Internationalis 2009;47(2):229.

7. Mathwig F. 10 questions - 10 réponses Le malheur ne doit pas créer l'injustice-Regard éthique sur le triage aux soins intensifs pendant la pandémie de Covid-19. Église évangélique réformée de Suisse. 2020. Available from: https://www.diaconie.ch/ wp-content/uploads/sites/2/2020/11/EERS_10questions-10-reponses_Triage_20201127-1.pdf.

8. Deutscher Ethikrat. Solidarität und Verantwortung in der Corona-Krise Adhoc-Empfehlung. Berlin 2020. Available from: https://www.ethikrat.org/fileadmin/ Publikationen/Ad-hoc-Empfehlungen/deutsch/ ad-hoc-empfehlung-corona-krise.pdf

9. Lewandowski K, W. SK. Beatmung, Triage und Scoring - Anmerkungen zur Situation in Europa zu Beginn der COVID-19-Pandemie In: Woesler Martin SH-M, editor. Medizin und Ethik in Zeiten von Corona. Münster ; Berlin: LIT; 2020. p. 35-52.

10. Piscitello GM, Kapania EM, Miller WD, Rojas JC, Siegler M, Parker WF. Variation in ventilator allocation guidelines by US state during the coronavirus disease 2019 pandemic: a systematic review. JAMA network open 2020;3(6):e2012606.

11. British Medical Association. COVID-19 ethical issues. A guidance note 2020. Available from: https://www.bma.org.uk/media/2226/ bma-covid-19-ethics-guidance.pdf.

12. Harvey D, Gardiner D, McGee A, DeBeer T, Shaw D. CRITCON-Pandemic levels: A stepwise ethical approach to clinician responsibility. J Intensice Care Soc. 2020;0(0):1-8. doi. org/10.1177/1751143720950542

13. Deutsche Interdisziplinäre Vereinigung für Intensiv- und Notfallmedizin. Entscheidungen über die Zuteilung von Ressourcen in der Notfall- und der Intensivmedizin im Kontext der COVID-19- Pandemie, Version 2.16.04.2020, Available from: https://www.divi.de/ joomlatools-files/docman-files/publikationen/ covid-19-dokumente/200417-divi-covid-19ethik-empfehlung-version-2.pdf

14. Österreichische Gesellschaft für Anaesthesiologie, Reanimation und Intensivmedizin. Allokation intensivmedizinischer Ressourcen aus Anlass der Covid-19-Pandemie. Klinisch-ethische Empfehlungen für Beginn, Durchführung und Beendigung von Intensivtherapie bei Covid19-PatientInnen.17.03.2020, Available from: 
https://www.oegari.at/web_files/cms_daten/ covid-19_ressourcenallokation_gari-statement_ v1.7_final_2020-03-17.pdf

15. Belgian Society of Intensive care medicine. Ethical principles concerning proportionality of critical care during the 2020 COVID-19 pandemic in Belgium. 2020. Available from: https://www.zorgneticuro.be/sites/default/files/ general/COVID-19-ethical_final_c.cleaned.pdf

16. Montgomery J, Stokes-Lampard HJ,Griffiths MD,Gardiner D, Harvey D, Suntharalingam G. Assessing whether COVID-19 patients will benefit from critical care, and an objective approach to capacity challenges during a pandemic: an intensive care Society clinical guideline. J Intensive Care Soc 2021;22(3):20410.

17. Schweizerische Akademie der Medizinischen Wissenschaften. Covid-19-Pandemie: Triage von intensivmedizinischen Behandlungen bei Ressourcenknappheit Version 3. 04.11.2020, Available from:samw.ch/de/coronavirus

18. Vergano, M., Bertolini, G., Giannini, A. et al. Clinical ethics recommendations for the allocation of intensive care treatments in exceptional, resource-limited circumstances: the Italian perspective during the COVID-19 epidemic. Crit Care 2020;24:165

19. Académie suisse des sciences médicales. Pandémie Covid-19: Triage des traitements de soins intensifs en cas de pénurie des ressources. 2020, Available from: https://sfar.org/download/ pandemie-covid-19-triage-des-traitementsde-soins-intensifs-en-cas-de-penurie-desressources/?wpdmdl $=25743 \&$ refresh $=616$ ab208896351634382344

20. Comité Consultatif National d'Ethique. COVID-19 contribution du comité consultatif national déthique: enjeux éthiques face à une pandémie.13.03.2020, Available from:https:// www.ccne-ethique.fr/sites/default/files/ publications/reponse_ccne_-_covid-19_def.pdf

21. Gelinsky K. Triage-Empfehlungen grenzüberschreitend betrachtet - Eine Befragung europäischer Intensivmediziner Konrad Adenauer Stiftung. 2020. Available from: https:// www.kas.de/de/einzeltitel/-/content/triageempfehlungen-grenzueberschreitend-betrachtet.

22. Hübner J, Schewe DM, Katalinic A, Frielitz F-S. Rechtsfragen der Ressourcenzuteilung in der COVID-19-Pandemie-Zwischen Utilitarismus und Lebenswertindifferenz. Deutsche Medizinische Wochenschrift (1946). 2020;145(10):687.

23. White DB, Lo B. A framework for rationing ventilators and critical care beds during the COVID-19 pandemic. JAMA. 2020;323(18):1773-4.

24. Marckmann G. Triage - wer wird behandelt, wer nicht? 2020. Available from: https://grueneeuropa.de/files/doc/docs/890899b2c778046003c c2b419e8912b3.pdf.

25. Bundesärztekammer. Orientierungshilfe der Bundesärztekammer zur Allokation medizinischer Ressourcen am Beispiel der SARS-CoV-2-Pandemie im Falle eines Kapazitätsmangels.Dtsch Arztebl 2020; 117(20): A-1084 / B-912

26. Sante et Service Sociaux Québec.Triage pour l'accès aux soins intensifs (adultes et pédiatriques) et l'allocation des ressources telles que les respirateurs en situation extrême de pandémie. 01.04.2020, Available from: https://publications. msss.gouv.qc.ca/msss/fichiers/directives-covid/ archives/1-Protocole_national_triage_aux_ Soins_intensifs-pandemie.pdf

27. Emanuel EJ, Wertheimer A. Who should get influenza vaccine when not all can? Science 2006;312(5775):854-5.

28. White DB, Katz MH, Luce JM, Lo B. Who should receive life support during a public health emergency? Using ethical principles to improve allocation decisions. Ann Intern Med. 2009;150(2):132-8.

29. Wang K, Zhang Z, Yu M, Tao Y, Xie M. 15day mortality and associated risk factors for hospitalized patients with COVID-19 in Wuhan, China: an ambispective observational cohort study. Intensive Care Med. 2020;46(7):1472-4.

30. İlkılıç İ. Yoğun Bakım Ünitelerindeki Kararlarda Yaşlılığın Normatif Anlamı. Türkiye Klinikleri J Med Ethics Law Hist-Special Topics 2016;2(2):1826.

31. Deutsche Gesellschaft für Osteogenesis imperfecta (Glasknochen) Betroffene e. V. Stellungnahme der DOIG zur aktuellen Diskussion über die Zuteilung von 
Ressourcen Triage in der Notfall- und Intensivmedizin bei Covid-19-Erkrankten. 2020, Available from: https://abilitywatch.de/ wp-content/uploads/2020/04/PM_Triage_OIGesellschaft-20.04.2020.pdf

32. Maves RC, Downar J, Dichter JR, Hick JL, Devereaux A, Geiling JA, et al. Triage of scarce critical care resources in COVID-19: an implementation guide for regional allocation An expert panel report of the Task Force for Mass Critical Care and the American College of Chest Physicians. Chest 2020;158(1):212-25.

33. Goold SD. The COVID-19 pandemic: Critical care allocated in extremis. Am J Bioeth. 2020;158(1):212-25.

34. Emanuel EJ, Persad G, Upshur R, Thome B, Parker M, Glickman A, et al. Fair allocation of scarce medical resources in the time of Covid-19. N Engl J Med 2020;382(21):2049-55.
35. Rehmann-Sutter C. Ethik der Triage bei überforderter Intensivpflege. Triage Priorisierung intensivmedizinischer Ressourcen unter Pandemiebedingungen. 24.03.2020. Available from: https://www.ethikrat.org/ fileadmin/PDF-Dateien/Veranstaltungen/fb2021-03-24-transkription.pdf

36. Nuffield Council on Bioethics. Ethical Considerations in Responding to the COVID-19 Pandemic. 20202020. Available from: https:// www.nuffieldbioethics.org/publications/ethicalconsiderations-in-responding-to-the-covid-19pandemic\#: :text=People\%20should\%20be\%20 treated $\% 20$ as, and $\% 20$ self $\% 2$ Disolation $\% 20$ are\%20implemented.

37. Joebges S, Biller-Andorno N. Ethics guidelines on COVID-19 triage-an emerging international consensus. Crit Care 2020;24(1):201.) 